\title{
The Strategy of Avoidability in the Skill Based on Students Participants Study Program for Educational Languages and Literature Indonesia PGRI University Adi Buana Surabaya
}

\author{
Luluk Isani Kulup \\ Universitas PGRI Adi Buana Surabaya \\ Surabaya, Indonesia \\ luluk@unipasby.ac.id.
}

\begin{abstract}
The avoidance strategy as part of a communication strategy is the effort of the language user in realizing what he thinks of when avoiding either some or all of the information that it deems inappropriate to choose a simpler form by providing sufficient information to make communication work smoothly. Basic teaching skill is a skill that must be possessed by teacher and education students to face the practice of apprentices III where communication skills are required that require the use of language rules according to the specific context and theme in the plan they are developing. In this case the students are required to communicate during the learning activities take place, while the concerned often do avoid-avoidance in communication that inhibits the smooth process of learning. The theory underlying this research is the typology of Dornyei, which sees that avoidance strategy is a strategy that language users do to ignore the unfinished message due to language difficulties. This study aims to describe the form and implementation of avoidance strategies undertaken by students apprentices II Program of Language Education and Literature Studies Indonesia University PGRI AdiBuana Surabaya. The approach used is qualitative. This approach is considered relevant because it accentuates its natural role, uses descriptive data, attaches importance, and uses inductive means because it does not intend to test the hypothesis. The data in this study are the verbal and nonverval behavior of the apprentice II students. The data source of this research is a student of the class of 2015 who takes the apprentice course II. The data collection technique used is observation. The procedure used to collect data that is 1 ) determine the pattern used to collect data, 2) make observations, 3 ) create a data format to facilitate data units and relationships between data. The instruments used in this study are various verbal, nonverbal, audio, and visual media. The results of this study indicate that the topic avoidance strategy dominates the basic teaching skill practice.
\end{abstract}

Keywords-Communication Strategy; Avoidance Strategy; Basic Teaching Skills; Student

\section{INTRODUCTION}

The Magang II course is a subject that must be followed by students after taking the lesson planning and apprentices course I semester before. This course includes a group of courses of work (MPB). The purpose of the course is so that students are able to apply approach, strategy, method, and technique in Indonesian language and literature learning practice. Through the application, it is expected that the students as prospective educators have a pedagogic competence.

Pedagogic competence is one of the competencies that must be owned by educators to become professional educators. According to Law No. 14 of 2005 Article 10, there are four competencies, namely professional competence, personality, social, and pedagogic. Pedagogic competence is the ability to manage to learn for learners. These competencies include (1) the ability to understand the characteristics of learners; (2) the ability to design, implement, and assess learning; (3) the ability to apply learning theory relevant to learners and the characteristics of the subjects, for example: implementing innovative learning. In addition to pedagogic competence, students are required to be able to communicate with colleagues when the practice of learning takes place. In order for learning to take place properly, it takes a variety of communication strategies to achieve a harmonious relationship between students as prospective teachers with peers.

In fact, based on observation and evaluation, there are still many obstacles faced by students in apprenticeship II. These constraints occur when students interact, both when interacting with peers and when with real students (at the time of microteaching). First, the need to communicate well, while students have not mastered the technique of interacting in accordance with the rules of learning. This relates to the experience of the students when getting the related subject, that is the learning subject which is presented in the form of theory without applying in the form of basic teaching praxis. Second, the communication strategy used is much influenced by the student's first language, not infrequently this strategy to rule out linguistic rules. Third, the lack of motivation of students in interacting and communicating in the right way will affect the sustainability of the communication process.

In the process of communication, often the process of negotiation, delivery of messages, efforts to instill the concept, influence, and others. Of course, these processes are interconnected with each other, but not infrequently the 
students will use one of the four processes. It may be done by students as prospective teachers because of difficulty in choosing the meaning of words, the selection of sentence form, and difficulty in choosing the "rule of speaking" (Merdhana, 2003: 43). Not infrequently also the difficulty of choosing how to communicate with colleagues caused by the differences of knowledge that exist between them.

Associated with it in a delivery of messages or ideas during the learning process of course often occurs artist (shrinkage meaning) in communication that is not realized by the students. Therefore, students are required to use communication strategies to minimize the occurrence of an attrition. Departing from that, this research is focused to describe communication strategy that emerged in basic skill of teaching on apprentice II, especially the most important part of communication strategy, that is avoidance strategy. In addition, in this study did not take into account the effects of communication caused by the strategy used by students. So, researchers only look at the utilization of avoidance strategies used by students during teaching practice activities ranging from initial activities, core activities, to closing lessons.his template, modified in MS Word 2007 and saved as a "Word 97-2003 Document" for the PC, provides authors with most of the formatting specifications needed for preparing electronic versions of their papers. All standard paper components have been specified for three reasons: (1) ease of use when formatting individual papers, (2) automatic compliance to electronic requirements that facilitate the concurrent or later production of electronic products, and (3) conformity of style throughout a conference proceedings. Margins, column widths, line spacing, and type styles are built-in; examples of the type styles are provided throughout this document and are identified in italic type, within parentheses, following the example. Some components, such as multi-leveled equations, graphics, and tables are not prescribed, although the various table text styles are provided. The formatter will need to create these components, incorporating the applicable criteria that follow.

\section{THEORETICAL REVIEW}

Communication is the process of exchanging information by two or more persons through verbal and nonverbal symbols, oral, written or visual codes, and involving production and compensation processes (Brown, 2007: 148). When communicating, the speaker always tries to convey his ideas effectively, the job of the speaker to capture the message or ideas as the speaker means. However, reality shows another. Often communication is not effective because the speaker can not catch the message as the speaker intended. It often happens to language users who have not been able to master the target language well. To overcome this, speakers need to use certain communication strategies.

Tarone (1983, p.6); (Brown, 2007, p. 180); (Cook, 2008, p 107-108) states that communication strategy is a potentially conscious plan to solve individual problems on their own in achieving certain communicative goals. In addition, this strategy consciously or unconsciously, contributes to the development of the acquisition of the first language learned by adults in the context of learning a second language. In the context of learning, communication strategies will facilitate communication between teachers and students when teachers can overcome interaction problems by choosing appropriate vocabulary, phrases, or sentences, so that understanding of meaning as part of communication objectives is easy to achieve. This is by Faerch and kasper (1983, p.25) it is stated that in order to achieve the desired communicative purpose, various devices are needed to achieve meaning or abandon meaning to achieve the goal by using appropriate communication strategies.

In other words, a communication strategy is an attempt to bridge the gap between the linguistic competence of language users and linguistic competence of the other person in real communication and by Dornyei (1995, P. 55) stated that communication strategy needs to be taught and learned by the linguist in improving the fluency of speech. Dornyei also proposes that this strategy should be taught by certain procedures that can be implicitly conveyed in language classes whose purpose is 1) to raise the learner's awareness of his / her communitative competence in order to be used in appropriate situations and to realize that communication strategies are very effective, 2) motivate the learner by taking risks to manipulate the available language without the fear of making mistakes, 3) the teacher can present the material about various video shows, conversation recordings and then discuss them with strategies used in the daily learner's life, 4) teach communication strategies implicitly presenting the linguistic tools needed to be disclosed directly, 5) providing the opportunity to practice in the use of the necessary strategies because the communication strategy can fulfill its function when directly used in real situations .

One form of communication strategy that is often used to achieve understanding of the meaning and avoid misunderstanding of language is avoidance strategy. Faerch and Kasper (1983, p.39) call it a reduction strategy, a system strategy to avoid non-fluent or false results in the realization of less automated rules, such as phonological, morphological, syntactic, and lexical forms. This strategy is an attempt of someone to avoid making mistakes or increasing fluency in saying. On the other hand (Brown, 2000: 127) explains that avoidance strategy is a cognitive and semantic manifestation when one avoids all topics that may be felt to be linguistically inappropriate. Or someone who for the same reason releases a particular message to choose a simpler structure and provide enough information to keep the communication going.

Littlewood (1983, p. 83) defines avoidance strategies as a learner/user effort aware of gaps or weaknesses in their repertoire, a clear strategy is to try to avoid opportunities that will present difficulties, competing speakers to take turns to avoid actively participating in discussions and avoiding discussing topics that they know they do not have sufficient vocabulary and Tarone (1983) categorizes avoidance strategies consisting of message avoidance strategies and topic avoidance strategies. avoidance strategies are avoided by problems that interfere with the purpose of communication. Likewise, Dornyei (in Brown, 2007: 138) and Cook (2008: 106-111) categorize avoidance strategies consisting of message avoidance strategies and topic avoidance strategies. Message avoidance strategy is a strategy that is done by 
leaving messages unfinished due to language difficulties. The strategy of avoidance of the topic is a strategy that is done by expressing the lexical meaning of the target language based on the knowledge of the meaning of the language they have or someone who for the same reason releases a particular message to choose a simpler structure and provide enough information to keep the communication going.

Pringgowidagdo (2002: 124) mentions an avoidance strategy under the name of a reduction strategy, a strategy for message avoidance under the name of a formal reduction strategy, and a topic avoidance strategy under the name of a formal reduction strategy. A formal reduction strategy is done through the avoidance of target language rules because the learner cannot achieve the desired goal easily. The functional strategy is done through avoidance on certain topics. Thus it can be stated that avoidance strategy is the effort of the language user in overcoming communication difficulties by avoiding the message and avoiding certain topics based on the knowledge they have to achieve the desired goal.

\section{RESEARCH METHOD}

This research uses descriptive qualitative research design. The design of this study was chosen because it is able to describe completely the avoidance strategy done by the students during the internship practice II.

Subjects in this study is a student of Indonesian language and ltarature education program studying apprenticeship II. The object of this research is avoidance strategies that are undertaken during learning from opening practice, core, and closing lessons.

The data collection used is observation, documentation, refer to the record. Data analysis was done by using three techniques: (1) dividing technique, (2) reverse technique, (3) connecting techniques (Dey in Ghony and Almanshur, 2012, Sudaryanto (1992). The data are used as instruments of data analysis when performing (1) data reduction in order to see the data units (2) data presentation in order to see the data thoroughly.Through the table, the data for each aspect studied and the relationship betweenpaspek seen so that makes it easy to make interpretation and make a conclusion.:

\section{RESUlT AND DisCUSSION}

Based on the research results obtained two things: the use of message avoidance strategy and avoidance strategy topic. Both of these strategies dominate during learning, both when the student begins the learning until it ends. The use of both strategies can be seen in the data below.

\section{a. Message Avoidance Strategy}

1) selanjutnya, eee.. model pembelajaran hari ini kita memakai number head together, di sini number head together ibu akan membagi kalian me... menjadi beberapa kelompok eee.. trus eee.. di setiap kelompok itu terdiri dari 5 orang, eee... di sini ibu akan mengasih kalian nomer, di nomer ini kita akan mengundi nomer berapa yang harus maa... eee... mempresentasikan hasil diskusi kalian nanti.
2) Silahkan dikerjakan tugasnya! Ibu sudah punya lembar jawaban di jawaban selanjutnya, silahkan diisi sesuai dengan yang dibahas oleh kelompok kalian! Apakah ada kesulitan?

3) Gr : Baik! Di sini ibu mempunyai evaluasi kembali, penegasan ....adakah kalian yang tau ciri-ciri puisi deduktif? Bagaimana? Apa saja? Bikin penguatan materi tadi, ibu rasa kan kalian sudah paham e... ibu mengulas kembali e... Puisi naratif itu apa?

Sis : Puisi yang mengandung suatu cerita.

$\mathrm{Gr}$ : Naratif?

Sis : Ya sudah, itu tadi Bu.

Gr : Maksudnya puisi lirik?

Sis : Puisi pengalaman.

Gr : Baik! Puisi deskriptif?

Sis : Puisi yang berisi suatu pesan.

Gr : baik, ibu rasa kalian sudah cukup paham dengan materi hari ini, e... buka buku kalian halaman 24 tugas kalian kerjakan di rumah, sudah paham gimana tugasnya?

If it is observed, it can be explained that in the data 1) the subject seems difficult to convey the definition of model Number Head Together, the subject tries to open the lesson by informing the model in question, but not followed by the explanation of the model that has been submitted, the subject left the message and replaced it with sharing information group in discussion. Below on the data 2) the subject tries to give the task to the students, but it seems difficult to convey the term LKPD by replacing it with the phrase 'Ibu sudah mempunyai lembar jawaban di jawaban selanjutnya' the subject actually wants to convey that the answer sheet is already available in LKPD with the page in question. Repeated word 'answer' in the sentence can be replaced with the word 'halaman"

Explanation of data 3) relating to closing skills, subjects try to end the lesson by reviewing the material presented earlier. If we look closely, it seems that the subject is trying to define what is related to the characteristics of poetry, but cannot be submitted properly because most subjects ask back to their students when there are a phrase 'Ibu akan mengulas kembali'. In the beginning the subject conveys the question 'Adakah kalian yang tahu ciri-ciri puisi deduktif?' The intended subject is actually the question of 'puisi deskriptif', but the emerging 'puisi deduktif'. This question has not been answered by the participants but has been continued with another question 'tentang puisi naratif'. If observed, the sentences conveyed the subject is not well structured, which led to a variety of unclear meanings. When it comes to the strategy used, the subject eliminates the vocabulary that ought to exist and elicits unnecessary vocabulary.

In data 4 below, the subject tries to inform the material to be presented when opening the lesson, but material information cannot be submitted properly. It is marked with 
the phrase 'di pagi hari ini', this phrase should be followed by upcoming material information, but it does not happen because the subject does various possibilities, 1) the subject accidentally avoids some vocabulary that should be conveyed, 2) the subject forgot to deliver the next sentence, 3) the subject forgot the subject matter of the day. The actual subject will start with the previous meeting information but what appears instead phrases that indicate the information to be presented that day.

4) Baik, di pagi hari ini sebelumnya di minggu yang lalukan kalian sudah mempelajari teks berita itu apa ya?

Based on these findings can be explained that the three subjects trying to convey information with different levels of difficulty. It appears that the difficulty is not only by changing the topic with other topics but also eliminating messages in the form of vocabularies that forget to be mentioned and asking for help to students (in this case is their peers). Faerch and Kasper (1983, p.39) suggest that a reduction strategy is a system for avoiding non-fluent or false results in the realization of less automated rules, such as phonological, morphological, syntactic, and lexical forms. This strategy is an attempt of someone to avoid making mistakes or increasing fluency in saying. This happens to all subjects when applying his basic teaching skills in apprenticeship II. In addition, other factors related to the background of subject experience affect the subject's smoothness in communicating. Tarone (1983) made it clear that the selection of strategies used by language users is influenced by a variety of factors, including interlinguistic systems in incompetent learners, learning situations, and communicative experiences of learners.

\section{b. Avoidance strategy topic}

5) Alhamdulillah, e.. baik sebelumnya ibu akan memberikan materi tentang mengidentifikasi unsur-unsur dalam teks puisi. Sebelumnya ibu akan memberikan tujuan pembelajaran. Hari ini e.. ibu kali ini akan menggunakan model pembelajaran e... e... itu apa namanya think pair share. jadi, kalian akan dibagi atas dua orang jadi sebangku aja ya e ibu akan memberikan tugas dan kalian akan mempresentasikan ke depan. Baik, e ibu akan mulai materi kali ini. Siapa yang tau tentang puisi? ... Sudah ada yang tau?

6) Bagus, e... tadi contoh yang tadi disebutkan oleh temanteman kalian berhubungan dengan materi pembelajaran hari ini, yaitu teks eksplanasi. Oh, iya bapak lupa hari ini bapak akan menggunakan model pembelajaran snowball throwing, jadi bapak punya bola, bola ini untuk siapa yang akan maju mempersentasikan mewakili kelompoknya dan bola ini nanti akan keliling satu-satu dan diikuti nyanyian, kita nyanyi lagu apa?

7) Eee... Baik, jawabannya sudah benar, di sini ibu memberi simpulan puisi ini tentang Eee.. seorang anak yang disuruh oleh orang tuanya untuk meng... apa? Untuk menghadapi kehidupan di luar sana, Baik Eee.... Ada yang perlu ditanyakan lagi?
In data 5), it can be explained that the subject avoids topics in opening lessons. The 'previous' word on the data is repeated twice by the subject in an effort to bridge the way the subject unlocks the lesson, but the subject leaves some to be explained, suppose the subject should convey the learning objectives of the day. The next subject does not explain the intended model of think pair share. In data 6), the subject conveys the learning model to be used, but the subsequent explanation is the syntax of the model. The syntax is also not well explained because many subjects avoid the information that should be correctly submitted. In the data 7) the subject avoids the topic while avoiding important messages to be conveyed to students / peers.

Based on the explanation it can be stated that on data5), 6 ), and 7) the subject is actually trying with his ability to convey important information to his peers. However, due to the limitations of the language system, the subject's experience in communicating, lack of practice, and limited comprehension of the topics conveyed made information not well conveyed although various strategies have been used by the subject.

\section{CONCLUSION}

Based on the results of research can be concluded that the avoidance strategy conducted by the subject when the internship practice II consists of 1) avoidance of topics and 2) avoidance of messages. This is because the subject is less competent on the submitted material, the communicative experience of the subject, and the underlying circumstances of the subject when interacting. In addition, the ability to cooperate with the subject of his subjects will greatly assist the smooth interaction without the help of others.

\section{Acknowledgment}

The researchers would like to thank the Head of Indonesian Language and Literature Studies Program, the Dean of the Faculty of Teacher Training and Education, and the Rector of PGRI University Adi Buana Surabaya who always gave moral and material support to the progress of the lecturers.

\section{References}

Brown, D. H. (2007). Principles of language learning and teaching. New York: Pearson Education.

Cook, V. (2008). Second language learning and language teaching. Fourth Edition. Hodder Education: An Hachette Uk Company.

Dornyei, Z. (1995). On the teachability of communication strategies. Tesol Quarterly, 21, 55-85.

Faerch, C., \& Kasper, G. (1983a). Plant and strategies in foreign language communication. In C. Faerchdan G. Kasper (Eds), Strategies in Interlanguage Communication (pp. 210-238). London: Longman. 
Faerch, C., \& Kasper, G. (1983b). Strategies competence in foreign language teaching. In G. Kasper (Ed), Learning, Teaching and Communication in The Foreign language Classroom (pp. 179-193). Aahus, German: Aarhus University Press

Ghoni \& Almanshur. (2012). Metodologi penelitian kualitatif. Yogyakarta: Ar-ruzz.
Pringgowidagdo, S. (2002). Strategi penguasaan berbahasa. Yogyakarta: Adi Cita.

Tarone, E. (1983). Some thoughts on the notion of communication strategy. in Faerch, Claus. \& Kasper, Gabriele (Eds) Strategies Interlanguages Communication. London: Longman. 